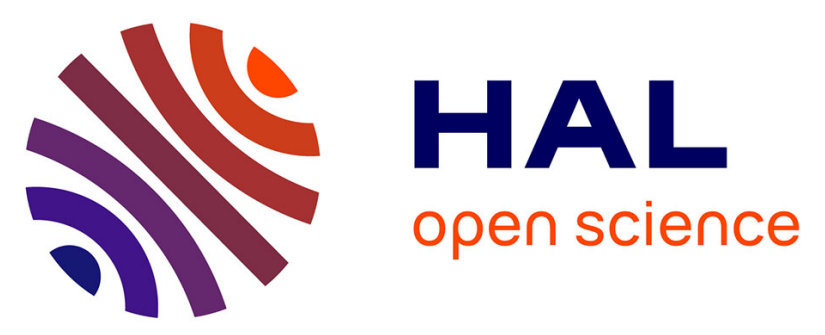

\title{
Can urban consolidation limit local biodiversity erosion? Responses from carabid beetle and spider assemblages in Western France
}

\author{
Marion Varet, Francoise Burel, Julien Pétillon
}

\section{- To cite this version:}

Marion Varet, Francoise Burel, Julien Pétillon. Can urban consolidation limit local biodiversity erosion? Responses from carabid beetle and spider assemblages in Western France. Urban Ecosystems, 2014, 17 (1), pp.123-137. 10.1007/s11252-013-0307-2 . hal-00999573

HAL Id: hal-00999573

https://hal-univ-rennes1.archives-ouvertes.fr/hal-00999573

Submitted on 16 Jun 2014

HAL is a multi-disciplinary open access archive for the deposit and dissemination of scientific research documents, whether they are published or not. The documents may come from teaching and research institutions in France or abroad, or from public or private research centers.
L'archive ouverte pluridisciplinaire HAL, est destinée au dépôt et à la diffusion de documents scientifiques de niveau recherche, publiés ou non, émanant des établissements d'enseignement et de recherche français ou étrangers, des laboratoires publics ou privés. 
2 Responses from carabid beetle and spider assemblages in Western France

4 Marion Varet ${ }^{\mathrm{a}, \mathrm{b}}$, Françoise Burel ${ }^{\mathrm{a}}$ and Julien Pétillon ${ }^{\mathrm{c}, *}$

5

6 a Université de Rennes 1, UMR CNRS 6553, 263 Avenue du Général Leclerc, CS 74205, 35042

7 Rennes Cedex, France

8

$9 \quad{ }^{\mathrm{b}}$ Rennes Métropole, Communauté d'agglomération rennaise, 4 Avenue Henri Fréville, CS

1020723,35207 Rennes Cedex, France

11

$12{ }^{\mathrm{c}}$ Université de Rennes 1, UMR 7204 - Muséum National d'Histoire Naturelle, 263 Avenue du

13 Général Leclerc, CS 74205, 35042 Rennes Cedex, France

14

15 *: Corresponding author. Tel: +33.22.323.68.51; Fax: +33.22.323.50.26. julien.petillon@univ-

16 rennes1.fr

17

18

19

20

21

22 


\section{Abstract}

3 During the last decades, urban consolidation has been developed to minimize spatial expansion

4 of cities, yet very few studies investigated whether it would actually reduce some negative

5 effects of urbanization on biodiversity. In this study, we compared the invertebrate assemblages

6 associated with two distinct urban forms (compact vs. conventional), focusing on two arthropod

7 taxa often used as bioindicators, and dominant in urban habitats: spiders and carabid beetles. The

8 following parameters were estimated: assemblage composition, species richness, activity-density

9 total, per species (excluding seldom-recorded species) and per size class. The field collection was

10 performed in 2009 using pitfall traps randomly set in hedgerows within 6 sites (representing 251

11 traps). A total of 4413 spiders belonging to 117 species and 2077 adult carabid beetles belonging

12 to 39 species were collected. We found few significant differences in carabid beetle and spider

13 assemblages between the two urban forms. The species richness of both groups was independent

14 from the neighborhood design. Only four species of carabid beetles and ten of spiders

15 significantly reacted to the neighborhood design, and no difference was found among the two

16 designs for all other species. Large carabid beetles were more abundant and small spiders less

17 abundant in the new neighborhood design compared to the conventional one. For both carabid

18 beetles and spiders, no difference in assemblage composition was found between neighborhood

19 designs. We therefore conclude that urban consolidation, by permitting a higher human density

20 with similar arthropod assemblages, could contribute to reduce biodiversity loss in cities.

22 Key words: City compaction; Araneae; Carabidae; housing density; arthropods 


\section{Introduction}

2 The world's urban population has increased considerably in the recent decades, reaching around

$350 \%$ of the global population at present (United Nations Population Division 2012). This growth

4 is accompanied by an increase in the urbanization of land (Weber 2003; Grimm et al. 2008), and

5 frequently, negative effects on biodiversity (McKinney 2002). For plants, a lower $\alpha$-diversity is

6 usually found in urban habitats compared to that in rural environments (e.g. McKinney 2002).

7 Arthropod species richness is also reported to decrease along rural to urban gradients (carabid

8 beetles: Niemelä and Kotze 2009, Magura et al. 2010; carabid beetles and spiders: Varet el al.

9 2011; arthropods in general: Gibb and Hochuli 2002, Kotze et al. 2011), with possible risks of

10 extinction predicted for several insect taxa (Fattorini 2011) and related changes in trophic

11 structure (Christie et al. 2010).

12 Given the spread of urban areas, it is thus important to understand the functioning of urban

13 ecosystems to plan the future development of cities and to minimize their negative

14 environmental impacts (Magura et al. 2004). Cities exhibit a specific environment in which the

15 conditions differ from those in natural habitats (Semenova, 2008), notably by the extent of

16 impervious surfaces (Weller and Ganzhorn 2004). However, the conservation of nature in the

17 city is increasingly important (Reduron 1996; Miller and Hobbs 2002; Jim and Chen 2008).

18 Currently, the desire and demand for nature in the city by urban residents and society in general

19 are clearly growing (Clergeau 2007). Thus, to meet these demands, new ways of thinking about

20 the city and new urban forms are developed, mostly to minimize their spatial expansion (Jenks et

21 al. 1996; Williams et al. 2000; Jenks and Dempsey 2005).

22 Urban consolidation, which aims at reducing the number of individual houses with gardens

23 (Grose 2009) in favor of grouped (semi-detached) or collective housing (Tratalos et al. 2007), is 
1 developing fast (Searle 2011) due to several proved or supposed advantages like limited urban

2 sprawl, a more efficient use of land, a more efficient use of services, some shorter travel

3 distances, or a lower carbon footprint (Dodson 2010). Yet some disadvantages may occur (longer

4 travel distances to nature, less green space within the city, stormwater/air quality issues, health

5 issues, crowding), and among them, possible negative consequences on biodiversity (Gray et al.

6 2010). Very few studies have investigated the consequences of urban consolidation on

7 biodiversity, despite obvious potential impacts (Tratalos et al. 2007). Green spaces, developed in

8 order to promote outdoor recreational activities, social interactions (Grose 2009; Rogers and

9 Sukolratanametee 2009) and environmental quality are used more and more by the public. Urban

10 green spaces can potentially contribute to enhancing biodiversity in the city (Kühn et al. 2004;

11 Jim and Chen 2008) including through the creation of microhabitat (Jim and Chen 2008). In

12 addition, the continuity of all the green areas is taken into account with the growing concept of

13 green urban corridors that are known to limit habitat fragmentation and to favor biodiversity

14 conservation (e.g. Vergnes et al. 2012). As a consequence, new neighborhood designs should

15 have higher housing density with a better continuity of public green space, thus promoting

16 increased connectivity for biodiversity. Conversely, conventional neighborhood designs are

17 likely characterized by a lower housing density, but with a strong fragmentation of public green

18 space.

19 The aim of the present study is to investigate whether and how the type of urban form will affect

20 two groups of arthropods (as a key component of biodiversity) in a single habitat type

21 (hedgerows, as an important habitat for urban biodiversity: Lövei et al. 2006) at a given time.

22 Spiders and carabid beetles were selected as model groups because they are known to react

23 strongly to changes in microhabitat conditions and therefore are often used as bioindicators 
1 (Marc et al. 1999; Bell et al. 2001; Luff et al. 1992; Rainio and Niemelä 2003; Pearce and Venier

2 2006). They are also among the most diversified groups of ground-dwelling arthropods in urban

3 habitats (e.g. Dias et al. 2006; Sattler et al. 2011; Vergnes et al. 2012). In this research we tested

4 the following hypotheses more specifically. Hypothesis 1: The new neighborhood designs with

5 more public green spaces and hedgerows should accommodate more species and individuals

6 (total and by species). Hypothesis 2: The conventional neighborhood designs with less dense and

7 more fragmented public green spaces and hedgerows should accommodate more species with

8 high dispersal ability (the mean size of species was used here as a broad, negative proxy of long-

9 distance dispersal abilities: Southwood 1962; Magura et al. 2006; Desender et al. 2008; yet large

10 species tend to cover longer distances when they actively disperse: Jenkins et al. 2007). The

11 assumed differences in landscape parameters between the two designs were also tested for our 12 six study sites.

\section{Materials and methods}

15 Study sites and sampling design

16 To compare new and conventional urban designs, six neighborhoods, three of each type, were

17 selected within the conurbation of Rennes (Fig. 1). They are located in six cities: Brécé $\left(\mathrm{N} 48^{\circ}\right.$

$1823^{\prime}, \mathrm{W} 0^{\circ} 48^{\prime}$, coded A), Vezin-le-Coquet (N 48 7', W $1^{\circ} 45^{\prime}$, coded B), Pacé (N 48 8', W $1^{\circ} 46^{\prime}$,

19 coded C) (A to C: conventional design), Chantepie ( $48^{\circ} 5^{\prime}$, W $1^{\circ} 37^{\prime}$, coded D), Saint Jacques

20 de la Lande (N 48 3', W $1^{\circ} 43^{\prime}$, coded E) and Le Rheu (N 48 6', W $1^{\circ} 48^{\prime}$, coded F) (D to F:

21 new design). All neighborhoods were built during the same period of time (between 1997 and

22 2000) and were adjacent to rural areas (field or meadow, so the colonization from surrounding

23 habitats is thus not seen as limited; Varet et al. 2011). Their area varied from 10 ha to 14.5 ha. All 
1 sites were mapped using ArcView by interpretation of orthophotographs (2006), cadastral data

2 and ground-truthing. Mean house density was two times higher in the new neighborhood design

3 compared to that in the conventional one (31 vs. 16 houses/ha, respectively).

4 Sample points were randomly selected (Arcview, Geo Wizards) within public hedgerows, and 5 spaced at least by 10 meters so that the traps were considered independent (Topping and

6 Sunderland 1992). Hedgerows were planted and designed at the creation of the neighborhood.

7 Each sample point consisted of one pitfall trap (diameter at the surface: $85 \mathrm{~mm}$ ) covered with a

8 plastic roof. The pitfall traps were filled with a preservation solution composed of $50 \%$

9 monopropylene glycol and 50\% aqueous salt solution of $100 \mathrm{~g} / \mathrm{l}$ (best fluid for collecting ground-

10 dwelling spiders; Schmidt et al. 2006). At each site, between 40 and 44 traps were set up and

11 collected (some traps were stolen or damaged during the sampling period, which was taken into

12 account by dividing the total catches of each trap by the effective collection, see below). The

13 pitfall traps were emptied every two weeks for eight weeks between mid-April 2009 and mid-

14 June 2009. The temporal sampling effort was consequently limited to favor a larger spatial extent

15 (e.g. Lövei and Magura 2011); other studies in the same area also showed that most carabid

16 beetle and spider species were collected during the spring compared to an annual sampling

17 (sampling in one site over 3 years and use of rarefaction methods in three sites; Varet 2011).

18 Each site was characterized by the following landscape variables: length, number and mean

19 length of public hedgerows, proportion of public green space, number and mean size of public

20 green patches, shortest distance between two patches and index of contagion. One meter around

21 each pitfall trap, the following parameters were measured: litter depth (from $1=$ thin to $3=$ thick),

22 presence of grass, shrub and tree strata, origin of plant species (local and/or exotic). 
2 Carabid beetles and spiders were preserved in $70 \%$ ethanol and stored in the University

3 collection (Rennes, France). Adult carabid beetles were identified using Jeannel (1941; 1942)

4 and Trautner and Geigenmüller (1987), whereas adult spiders were identified using Roberts

$5 \quad(1987 ; 1995)$ and Heimer and Nentwig (1991). Catches in pitfall traps were related to trapping

6 duration and pitfall perimeter in order to calculate an 'activity trappability density' (number of

7 individuals per day and per meter; Sunderland et al. 1995), further abbreviated as 'activity-

8 density'. Carabid beetles and spiders were classified into size classes (using mainly Roberts 1987

9 for spiders and Bouget 2004 for carabid beetles). The size classes (in mm, respectively size1,

10 size2, size 3 ) were $0-3,3-5, \geq 5$ for adult spiders and $0-5,5-10, \geq 10$ for carabid beetles.

12 Statistical analysis

13 We performed multivariate analyses of activity-density of all species using the software

14 CANOCO (ter Braak and Šmilauer 2002) in order to analyze the patterns of species composition

15 in the 6 sites. The choice between linear (Principal Component Analysis: PCA) or unimodal

16 (Correspondence Analysis: CA) analyses depended on the length values of the first axis gradient

17 previously realized with DCA (Detrended Correspondence Analysis). To test for differences in

18 activity-density (total, per species represented by more than $1 \%$ of total catches and per size

19 class) and species richness between the neighborhood designs, we used nested general linear

20 model (GLM) with a quasi-Poisson distribution performed using data from the individual traps

21 (Vincent and Haworth 1983; O’Hara and Kotze 2010). City was nested within neighborhood

22 design. The resulting data were analyzed with $\mathrm{R}$ software (R Development Core Team 2009)

23 using the glmmPQL package (e.g. Venables and Ripley, 2002). 


\section{Results}

3 Description of the neighborhood designs

4 The analysis of the landscape structure of the 6 neighborhoods from the 2 designs revealed that

5 the number of green patches and the length of public hedges were higher in the new

6 neighborhood design and that the index of contagion was almost significantly higher in the new

7 neighborhood design while the other parameters were not significantly different between the two

8 urban designs (Table 1). All sites were characterized by hedgerows with a medium-depth litter,

9 low percentages of herbaceous and tree strata, dense shrubs, and a dominance of local plant

10 species compared to exotic species (Table 1).

12 Description of the fauna

13 In total, 2077 carabid specimens belonging to 39 species were collected. Individuals of Nebria

14 brevicollis accounted for more than $50 \%$ of the total catch. The number of species varied

15 between the 6 neighborhoods (site A: 21, B: 21, C: 27, D: 17, E: 14, F: 20), as did the number of

16 individuals (site A: 249, B: 130, C: 423, D: 283, E: 158, F: 834). In total, 4413 spider specimens

17 belonging to 117 species were collected. Individuals of Pardosa hortensis, Pardosa prativaga,

18 Ozyptila praticola, Zodarion italicum, Dysdera erythrina and Trochosa ruricola accounted for

19 more than $40 \%$ of the total catch. The number of species and individuals were similar in all

20 neighborhoods (between 55 and 73 species; site A: 55, B: 73, C: 70, D: 71, E: 67, F: 58; and

21 between 616 and 891 individuals; site A: 714, B: 616, C: 891, D: 767, E: 742, F: 683).

23 Species assemblages vs. urban forms 
1 Axis 1 of the CA on carabid beetle assemblages (Fig. 2) represented $10.3 \%$ of inertia and Axis 2 ,

$28 \%$ of inertia. Axis 1 of the CA on spider assemblages (Fig. 3) represented 5.7\% of inertia and

3 Axis 2, 5\% of inertia. The neighborhood design variable on axis 1 and 2 of CAs was very close to

4 the origin for both groups, and neighborhood designs cannot be segregated by the global 5 composition of assemblages, (Figs. 2 and 3).

$7 \quad$ Species activity-density and richness vs. urban forms

8 The total activity-density of carabid beetles was significantly higher in the new neighborhood

9 design while the total activity-density of spiders and the species richness of both groups were

10 independent from the neighborhood design. Several species were significantly associated with

11 the neighborhood design. The carabid beetles Harpalus rufipes and N. brevicollis and the spider

12 D. erythrina were significantly more abundant in the new neighborhood design, while the

13 carabid beetles Asaphidion stierlini and Pterostichus melanarius and the spiders Agoeca inopina,

14 Alopecosa pulverulenta, Hahnia nava, Pachygnatha degeeri, Pardosa amentata, Pardosa

15 saltans, Phrurolithus festivus, T. ruricola and Z. italicum were significantly more abundant in the

16 conventional neighborhood design. Large carabid beetles (size class 3: Table 2) were more

17 abundant and small spiders (size class 1: Table 3) less abundant in the new neighborhood design

18 compared to the conventional one.

\section{Discussion}

21 From a strictly urbanistic point of view, the two urban forms are obviously distinct (type and

22 density of housing, coverage ratio, floor area ratio; Chapuis et al. 2005), but from a landscape

23 perspective, the distinction was less obvious in this study. In terms of composition, urban forms 
1 could be distinguished according to two parameters. The higher density and length of hedgerows

2 and the higher number of public green space patches in the new urban design are in accordance

3 with the goals aimed at the conception of these neighborhoods, and supported our hypotheses.

4 Regarding landscape connectivity, both urban forms were not really different. Indeed, whatever

5 the urban form, the neighborhood was split by dense public roads. This analysis at a landscape

6 scale of the two urban forms was yet based on six sites only, and nevertheless there was a trend

7 for the new, compact, urban form to offer a better connectivity between green habitats. The goals

8 set by new urban form designers are thus not all reached here.

9 Several, although not numerous, species had some population activity-densities dependent on

10 urban form. Most of these species were more abundant in neighborhoods of conventional design.

11 This can be explained by the fact that most of these species are generalist or open field species,

12 like the carabids Asaphidion stierlini and Pterostichus melanarius (Luff 1998; Bouget 2004) and

13 the spiders Agoeca inopina, Alopecosa pulverulenta, Pachygnatha degeeri, Pardosa amentata,

14 Phrurolithus festivus, T. ruricola and Z. italicum (Hänggi et al. 1995; Harvey et al. 2002).

15 Indeed, the conventional neighborhood has a lower density of public hedgerows and is

16 consequently likely to host more species preferring open environments. Yet, two forest species,

17 the spiders Hahnia nava and Pardosa saltans, were significantly more abundant in the

18 conventional design than in compact neighborhoods, but they occurred at low numbers in both

19 urban forms (although sufficient to be included in the individual species analysis). More

20 generally, forest species were little represented in both urban forms and species richness of

21 carabid beetles and spiders did not differ among the neighborhoods, contrary to our first

22 hypothesis with the activity-density of forest species not higher in new urban forms. This can be

23 partly due to the similarity of the urban forms when considering certain landscape indexes. 
1 Indeed, the diversity of assemblages is partly shaped by the landscape structure (e.g. Le Coeur et

2 al. 2002; Schmidt et al. 2005; Schweiger et al. 2005; Hendrickx et al. 2007). But habitat quality

3 (including frequency and intensity of disturbances) also determines the local presence of

4 specialist or generalist species. The lack of an effect of urban forms on species richness, as well

5 as the low occurrence of forest species, can then be also attributed to the similarity in quality and

6 management of the hedgerows between the two urban forms. It should be emphasized that

7 hedgerows in both new and conventional urban forms are managed by the same people, who

8 apply their skills independently from the urban form itself (in the conurbation of Rennes; Le

9 Rudulier 1994). Yet the management of green spaces made up of non-native species may re-

10 create and maintain some diversified assemblages (e.g. for carabid beetles; Magura et al. 2000),

11 intensive management is well-known to homogenize invertebrate faunas, and maintain species of

12 young successional stages even in older neighborhood (comparisons between 14 and 30 year-old

13 sites in the same study area; Varet et al. in press.).

14 Confirming our second hypothesis, the total activity-density of large individuals (carabid beetles)

15 was higher and small individuals (spiders) were lower in the new urban design than in the

16 conventional urban designs with individual houses and gardens. Large individuals (carabid

17 beetles), considered to have a lower dispersal capacity (den Boer 1977; Dajoz 2002), are more

18 numerous in new urban designs. These designs include more hedgerows and seem to offer a

19 better connectivity than conventional designs. New urban designs include more continuous

20 suitable elements, favoring the dispersal of large carabid individuals (Burel 1989), as opposed to

21 neighborhoods with more fragmented public green spaces and hedgerows due to individual

22 houses. Small individuals (spiders), considered as having a higher dispersal capacity (size and

23 mass limitation of long-distance dispersal in spiders; e.g. Coyle et al. 1985), were also more 
1 numerous in conventional neighborhoods. The lower number of hedgerows in these

2 neighborhoods allows for a better dispersal of small spiders using ballooning as a main dispersal

3 method (Dean and Sterling 1985), mostly by decreasing the number of barriers to (aerial)

4 dispersers (Larrivée and Buddle 2009).

5 Although obvious differences in some landscape parameters were highlighted, only slight,

6 mostly non-significant differences were found in arthropod assemblages, despite the use of

7 complementary biological models (e.g. Desender and Maelfait 1999; Pétillon et al. 2008). This

8 can be explained by the fact that urban environments, whatever their design, are considered

9 highly disturbed (Blair 1996; Ormerod 2003) and consequently host mostly species of young

10 successional stages. This study also underlines the need to conduct trait-based analyses on top of

11 classical species richness approach (see also Magura et al. 2008; Tóthmérész et al. 2011; Horváth

12 et al. 2012). As an applied conclusion, urban consolidation, by permitting a higher housing

13 density with similar arthropod assemblages, is likely to reduce biodiversity loss in cities.

\section{Acknowledgements}

16 We would like to thank Anne Treguier and Béatrice Sauzeau, Alain Canard, Robert Bosmans and

17 Christophe Hervé for their help in identifying carabid beetles and problematic spiders, 18 respectively. Sandrine Baudry, Aldyth Nys, two anonymous referees and the associated editor are

19 acknowledged for their comments on earlier drafts. This study was funded by Rennes Métropole 20 and the 'Ministère de l'Enseignement supérieur et de la Recherche' (grant 'CIFRE' to M.V.).

\section{References}


1 Bell JR, Wheater, CP, Cullen WR (2001) The implications of grassland and heathland

2 management for the conservation of spider communities: a review. J Zool 255:377-387

3 Blair RB (1996) Land use and avian species diversity along an urban gradient. Ecol Appl 6:506-

$4 \quad 519$

5 Bouget C (2004) Chablis et diversité des coléoptères en forets feuillus de plaine: Impact à court

6 terme de la trouée, de sa surface et de son contexte paysager. $\mathrm{PhD}$, Museum National

7 d'Histoire Naturelle, Paris

8 Burel F (1989) Landscape structure effects on carabid beetles spatial patterns in western France,

$9 \quad$ Landscape Ecol 2:215-226

10 Chapuis J-Y, Hardy E, Guisti J (2005) Villes en évolution. La documentation française, Paris

11 Christie FJ, Cassis G, Hochuli DF (2010) Urbanization affects the trophic structure of arboreal

12 arthropod communities. Urban Ecosyst 13:169-180

13 Clergeau P (2007) Une écologie du paysage urbain. Apogée, Rennes

14 Coyle FA, Greestone MH, Hultsch AL, Morgan CE (1985) Ballooning mygalomorphs: estimates

15 of the masses of Sphodros and Ummidia ballooners (Araneae: Atypidae, Ctenizidae). J

16 Arachnol 13:291-296

17 Dajoz R (2002) Les Coléoptères Carabidés et Ténébrionidés. Tec \& Doc, Paris

18 Dean DA, Sterling WL (1985) Size and phenology of ballooning spiders at two locations in 19 eastern Texas. J Arachnol 13:111-120

20 den Boer PJ (1977) Dispersal power and survival of carabids in a cultivated countryside. Misc

21 Pap LH Wageningen 14:1-190

22 Desender K, Dekoninck W, Maes D, Crevecoeur L, Dufrêne M, Jacobs M, Lambrechts J, Pollet

23 M, Stassen E, Thys N (2008) Een nieuwe verspreidingsatlas van de loopkevers en 
zandloopkevers (Carabidae) in België. Rapporten van het Instituut voor Natuur- en

2 Bosonderzoek. Instituut voor Natuur- en Bosonderzoek, Brussels

3 Desender K, Maelfait J-P (1999) Diversity and conservation of terrestrial arthropods in tidal

4 marshes along the River Schelde: a gradient analysis. Biol Conserv 87:221-229

5 Dias SC, Brescovit AD, Couto ECG, Martins CF (2006) Species richness and seasonality of

6 spiders (Arachnida, Araneae) in an urban Atlantic forest fragment in Northeastern Brazil.

$7 \quad$ Urban Ecosyst 9:323-335

8 Dodson J (2010) In the wrong place at the wrong time? Assessing some planning, transport and

9 housing market limits to urban consolidation policies. Urban Policy Res 28:487-504

10 Fattorini S (2011) Insect extinction by urbanization: A long term study in Rome. Biol Conserv

$11 \quad 144: 370-375$

12 Gibb H, Hochuli DF (2002) Habitat fragmentation in an urban environment: large and small

13 fragments support different arthropod assemblages. Biol Conserv 106:91-100

14 Gray R, Gleeson B, Burke M (2010) Urban consolidation, household greenhouse emissions and

15 the role of planning. Urban Policy Res 28:335-346

16 Grimm NB, Faeth SH, Golubiewski NE, Redman CL, Wu J, Bai X, Briggs JM (2008) Global

17 change and the ecology of cities. Science 319:756-760

18 Grose MJ (2009) Changing relationships in public open space and private open space in 19 suburbans in south-western Australia. Landscape Urban Plann 92:53-63

20 Hänggi A, Stocklie E, Nentwig W (1995) Habitats of central European spiders. Centre Suisse de 21 cartographie de la faune, Neuchâtel 
1 Harvey PR, Nellist DR, Telfer MG (2002) Provisional Atlas of British Spiders (Arachnida,

2 Araneae), Volumes 1 and 2. Biological Records Centre, Huntington, Cambridgeshire

3 Heimer S, Nentwig W (1991) Spinnen Mitteleuropas. Verlag Paul Parey, Berlin

4 Hendrickx F, Maelfait J-P, Van Wingerden W, Schweiger O, Speelmans M, Aviron S, Augenstein

5 I, Billeter R, Bailey D, Bukacek R, Burel F, Diekötter T, Dirksen J, Herzog F, Liira J,

6 Roubalova M, Vandomme V, Bugter R (2007) How landscape structure, land-use intensity

7 and habitat diversity affect components of total arthropod diversity in agricultural

$8 \quad$ landscapes. J Appl Ecol 44:340-351

9 Horváth R, Magura T, Tóthmérész B (2012) Ignoring ecological demands masks the real effect

10 of urbanization: a case study of ground-dwelling spiders along a rural-urban gradient in a

11 lowland forest in Hungary. Ecol Res 27:1069-1077

12 Jeannel R $(1941,1942)$ Faune de France 39 Coléoptères carabiques, première et deuxième 13 parties. Paul Lechevalier et fils Eds, Paris

14 Jenkins DG, Brescacin CR, Duxbury CV, Elliott JA, Evans JA, Grablow KR, Hillegass M, Lyon

15 BN, Metzger GA, Olandese ML, Pepe D, Silvers GA, Suresch HN, Thompson TN, Trexler

16 CM, Williams GE, Williams NC, Williams SE (2007) Does size matter for dispersal

17 distance? Global Ecol Biogeogr 16:415-425

18 Jenks M, Burton E, Williams K (1996) The compact city. A sustainable urban form? SPON, 19 London

20 Jenks M, Dempsey N (2005) Future forms and design for sustainable cities. Elsevier, Oxford

21 Jim CY, Chen WY (2008) Pattern and divergence of tree communities in Taipei's main urban 22 green spaces. Landscape Urban Plann 84:321-323 
1 Kotze DJ, Venn S, Niemelä J, Spence J (2011) Effects of urbanization on the ecology and

2 evolution of arthropods. In: Niemelä J et al (eds) Urban Ecology - Patterns, Processes, and

3 Application. Oxford University Press, Oxford, pp 159-166

4 Kühn I, Brandl R, May R, Klotz S (2004) The flora of German cities is naturally species rich. $5 \quad$ Evol Ecol Res 6:749-764

6 Larrivée M, Buddle CM (2009) Diversity of canopy and understorey spiders in north-temperate 7 hardwood forests. Agr Forest Entomol 11:225-237

8 Le Coeur D, Baudry J, Burel F, Thenail C (2002) Why and how we should study field boundaries

9 biodiversity in an agrarian landscape context. Agr Ecosyst Environ 89:23-40

10 Le Rudulier J (1994) Présentation de l'expérience de la ville de Rennes. CNFPT, Dijon

11 Lövei GL, Magura T (2011) Can carabidologists spot a pitfall? The non-equivalence of two 12 components of sampling effort in pitfall-trapped ground beetles (Carabidae)? Community $13 \quad$ Ecol 12:18-22

14 Lövei GL, Magura T, Tóthmérész B, Ködöböcz V (2006) The influence of matrix and edges on 15 species richness patterns of ground beetles (Coleoptera, Carabidae) in habitat islands. Global 16 Ecol Biogeogr 15:283-289

17 Luff ML (1998) Provisional atlas of the ground beetles (Coleoptera, Carabidae) of Britain. 18 Biological Records Centre, Huntington

19 Luff ML, Eyre MD, Rushton SP (1992) Classification and prediction of grassland habitats using 20 ground beetles (Coleoptera, Carabidae). J Environ Manage 35:301-315

21 Magura T, Lövei GL, Tóthmérész B (2010) Does urbanisation decrease diversity in ground 22 beetle (Carabidae) assemblages? Global Ecol Biogeogr 19:16-26 
1 Magura T, Tóthmérész B, Bordan ZS (2000) Effects of nature management practice on carabid

2 assemblages (Coleoptera: Carabidae) in a non-native plantation. Biol Conserv 93:95-102

3 Magura T, Tóthmérész B, Lövei GL (2006) Body size inequality of carabids along an

$4 \quad$ urbanisation gradient. Basic Appl Ecol 7:472-482

5 Magura T, Tóthmérész B, Molnar T (2004) Changes in carabid beetle assemblages along an

6 urbanisation gradient in the city of Debrecen, Hungary. Landscape Ecol 19:747-759

7 Magura T, Tóthmérész B, Molnár T (2008) A species-level comparison of occurrence patterns in

8 carabids along an urbanisation gradient. Landscape Urban Plann 86:134-140

9 Marc P, Canard A, Ysnel F (1999) Spiders (Araneae) useful for pest limitation and bioindication.

10 Agr Ecosyst Environ 74:229-273

11 McKinney ML (2002) Urbanization, biodiversity, and conservation. BioScience 53:883-890

12 Miller JR, Hobbs RJ (2002) Conservation where people live and work. Biol Conserv 16:330-337

13 Niemelä J, Kotze DJ (2009) Carabid beetle assemblages along urban to rural gradients: a review.

$14 \quad$ Landscape Urban Plann 92:65-71

15 O'Hara RB, Kotze DJ (2010) Do not log-transform count data. Methods Ecol Evol 1:118-122

16 Ormerod SJ (2003) Restoration in applied ecology: editor's introduction. J Appl Ecol 40:44-50

17 Pearce JL, Venier LA (2006) The use of ground beetles (Coleoptera: Carabidae) and spiders

18 (Araneae) as bioindicators of sustainable forest management: A review. Ecol Indic 6:780$19 \quad 793$

20 Pétillon J, Georges A, Canard A, Lefeuvre J-C, Bakker JP, Ysnel F (2008) Influence of abiotic

21 factors on spider and ground beetles communities in different salt-marsh systems. Basic

$22 \quad$ Appl Ecol 9:743-751 
1 R Development Core Team (2009) R: A language and environment for statistical computing. R

$2 \quad$ Foundation for Statistical Computing, Vienna

3 Rainio J, Niemelä J (2003) Ground beetles (Coleoptera: Carabidae) as bioindicators. Biodiv

$4 \quad$ Conserv 12:487-506

5 Reduron JP (1996) The role of biodiversity in urban areas and the role of cities in biodiversity

6 conservation. In: di Casttri F, Younès T (eds), Biodiversity, sciences and development:

7 Towards a new partnership. CAB International, Wallingford

8 Roberts MJ (1987) The spiders of Great Britain and Ireland, Volumes 1 and 2. Harley Books, $9 \quad$ Colchester

10 Roberts MJ (1995) Spiders of Britain and Northern Europe. Harper Collins Publishers, London

11 Rogers GO, Sukolratanametee S (2009) Neighbourhood design and sense of community:

12 comparing suburban neighbourhoods in Houston Texas. Landscape Urban Plann 92:325-334

13 Sattler T, Obrist MK, Duelli P, Moretti M (2011) Urban arthropod communities: added value or

$14 \quad$ just a blend of surrounding biodiversity? Landscape Urban Plann 103:347-361

15 Schmidt MH, Clough Y, Schulz W, Westphalen A, Tscharntke T (2006) Capture efficiency and 16 preservation attributes of different fluids in pitfall traps. J Arachnol 34:159-162

17 Schmidt MH, Roschewitz I, Thies C, Tscharntke T (2005) Differential effects of landscape and 18 management on diversity and density of ground-dwelling farmland spiders. J Appl Ecol $19 \quad 42: 281-287$

20 Schweiger O, Maelfait J-P, Van Wingerden W, Hendrickx F, Billeter R, Speelmans M, 21 Augenstein I, Aukema B, Aviron S, Bailey D, Bukacek R, Burel F, Diekotter T, Dirksen J, 22 Frenzel M, Herzog F, Liira J, Roubalova M, Bugter R (2005) Quantifying the impact of 
environmental factors on arthropod communities in agricultural landscapes across organizational levels and spatial scales. J Appl Ecol 42:1129-1139

3 Searle G (2011) Urban consolidation and the inadequacy of local open space provision in $4 \quad$ Sydney. Urban Policy Res 29:201-208

5 Semenova OV (2008) Ecology of ground beetles in an industrial city. Russ J Ecol 39:444-450.

6 Southwood TRE (1962) Migration of terrestrial arthropods in relation to habitat. Biol Rev $7 \quad 37: 171-214$

8 Sunderland KD, De Snoo GR, Dinter A, Hance T, Helenius J, Jepson P, Kromp B, Samu F, 9 Sotherton NW, Toft S, Ulber B (1995) Density estimation for invertebrate predators in 10 agroecosystems. In: Toft S, Riedel W (eds), Arthropod natural enemies in arable land. I. 11 Density, spatial heterogeneity and dispersal. Aarhus University Press, Århus, pp 133-162

12 ter Braak CJF, Šmilauer P (2002) CANOCO Reference Manual and User's Guide to Canoco for 13 Windows: Sofware for Canonical Community Ordination (version 4.5). Microcomputer 14 Power, Ithaca, New York

15 Topping CJ, Sunderland KD (1992) Limitations in the use of pitfall traps in ecological studies 16 exemplified by a study of spiders in a field of winter wheat. J App Ecol 29:485-491

17 Tóthmérész B, Máthé I, Balázs E, Magura T (2011) Responses of carabid beetles to urbanization 18 in Transylvania (Romania). Landscape Urban Plann 101:330-337

19 Tratalos J, Fuller RA, Warren PH, Davies RG, Gaston KJ (2007) Urban form, biodiversity 20 potential and ecosystem services. Landscape Urban Plann 83:308-317

21 Trautner J, Geigenmüller K (1987) Tiger beetles, ground beetles: illustrated key to the 22 Cicindelidae and Carabidae of Europe. Josef Margraf, Aichtal 
1 United Nations Population Division (2012) World urbanization prospects: the 2011 revision.

2 United Nations, Department of Economic and Social Affairs, New York

3 Varet M (2011) Biodiversité et aménagements urbains: réponse des assemblages de carabiques et

4 d'araignées dans les haies publiques de Rennes Métropole. PhD thesis, Université de Rennes

$5 \quad 1$, Rennes

6 Varet M, Burel F, Lafage D \& Pétillon J (In press) Age-dependant colonisation of urban habitats:

$7 \quad$ a diachronic approach using carabid beetles and spiders. Anim Biol

8 Varet M, Pétillon J, Burel F (2011) Comparative responses of spider and carabid beetle $9 \quad$ assemblages along an urban-rural ecotone. J Arachnol 39:236-243

10 Venables WN, Ripley BD (2002) Modern Applied Statistics with S. Springer Verlag, Berlin

11 Vergnes A, Le Viol I, Clergeau P (2012) Green corridors in urban landscapes affect the arthropod 12 communities of domestic gardens. Biol Conserv 145:171-178

13 Vincent PJ, Haworth JM (1983) Poisson regression models of species abundance. J Biogeogr $14 \quad 10: 153-160$

15 Weber C (2003) Interaction model application for urban planning. Landscape Urban Plan 63:49$16 \quad 60$

17 Weller B, Ganzhorn JU (2004) Carabid beetle community composition, body size, and 18 fluctuating asymmetry along an urban-rural gradient. Basic Appl Ecol 5:193-201

19 Williams K, Burton E, Jenks M (2000) Achieving sustainable urban form. SPON, London 20 
1 Table 1: Landscape indexes for each neighborhood and comparison of means between the two

2 urban designs (significance by Mann-Whitney tests indicated with bold font). Bold font indicates

3 significant difference among urban designs. For information, the following local parameters are

4 also provided: mean litter depth (see the scores in Material and Methods), occurrence of grass,

$5 \quad$ shrub and tree strata and local and exotic species.

\begin{tabular}{|c|c|c|c|c|c|c|c|c|}
\hline & \multicolumn{3}{|c|}{ New design } & \multicolumn{3}{|c|}{ Conventional design } & \multirow{2}{*}{ U-value } & \multirow{2}{*}{ p-value } \\
\hline & Site D & Site E & Site F & Site A & Site B & Site C & & \\
\hline length of public edges (m) & 281.6 & 335.5 & 252.9 & 138 & 221.1 & 95.5 & $\begin{array}{l}\mathrm{U} 1=0 \\
(\mathrm{U} 2=9)\end{array}$ & 0.0495 \\
\hline number of public edges & 6.4 & 9 & 9.1 & 3.6 & 9.1 & 1.5 & $\begin{array}{l}\mathrm{U} 1=2.5 \\
(\mathrm{U} 2=6.5)\end{array}$ & 0.3827 \\
\hline $\begin{array}{l}\text { mean length of public edges } \\
(\mathrm{m})\end{array}$ & 44.1 & 37.4 & 27.9 & 38.6 & 21.4 & 66 & $\begin{array}{l}\mathrm{U} 1=4 \\
(\mathrm{U} 2=5)\end{array}$ & 0.8273 \\
\hline $\begin{array}{l}\text { the proportion of public } \\
\text { green space }\end{array}$ & 34.4 & 34.3 & 13.3 & 12.3 & 22.6 & 11.6 & $\begin{array}{l}\mathrm{U} 1=1 \\
(\mathrm{U} 2=8)\end{array}$ & 0.1266 \\
\hline $\begin{array}{l}\text { number of public green } \\
\text { patches }\end{array}$ & 4.3 & 3.9 & 5.1 & 2.4 & 3.6 & 2.7 & $\begin{array}{l}\mathrm{U} 1=0 \\
(\mathrm{U} 2=9)\end{array}$ & 0.0495 \\
\hline $\begin{array}{l}\text { mean size of public green } \\
\text { patch (ha) }\end{array}$ & 756 & 884 & 261 & 502 & 621 & 421 & $\begin{array}{l}\mathrm{U} 1=3 \\
(\mathrm{U} 2=6)\end{array}$ & 0.5127 \\
\hline $\begin{array}{l}\text { the shortest distance } \\
\text { between two patches (m) }\end{array}$ & 5.3 & 4.2 & 6.3 & 8.1 & 4.4 & 9.9 & $\begin{array}{l}\mathrm{U} 1=2 \\
(\mathrm{U} 2=7)\end{array}$ & 0.2752 \\
\hline index of contagion & 35 & 36 & 38 & 35 & 32 & 34 & $\begin{array}{l}\mathrm{U} 1=0.5 \\
(\mathrm{U} 2=8.5)\end{array}$ & 0.0765 \\
\hline Mean litter depth & 2.23 & 1.80 & 1.43 & 1.86 & 1.71 & 1.84 & & \\
\hline Occurrence $(\%)$ of & & & & & & & & \\
\hline $\begin{array}{l}\text { Herbaceous stratum } \\
\text { Shrub stratum }\end{array}$ & $\begin{array}{l}43.18 \\
100\end{array}$ & $\begin{array}{l}40.91 \\
100\end{array}$ & $\begin{array}{l}11.36 \\
100\end{array}$ & $\begin{array}{l}42.11 \\
100\end{array}$ & $\begin{array}{l}32.56 \\
100\end{array}$ & $\begin{array}{l}55.26 \\
100\end{array}$ & & \\
\hline Tree stratum & 25.00 & 15.90 & 0 & 0 & 25.58 & 23.68 & & \\
\hline Native species & 68.18 & 51.16 & 81.81 & 97.37 & 74.42 & 50.00 & & \\
\hline Exotic species & 40.91 & 60.47 & 34.09 & 44.74 & 39.53 & 63.16 & & \\
\hline
\end{tabular}


1 Table 2. Result of the GLM analysis of the effect of neighborhood design (CD=Conventional design; ND=new design) on species richness and 2 activity-density (total, mean per species and per size class) for the most abundant carabid beetle species (i.e. represented by at least $1 \%$ of total 3 catches). Bold font indicates significant difference among urban designs.

\begin{tabular}{|c|c|c|c|c|c|c|c|c|c|c|c|}
\hline \multirow{3}{*}{$\begin{array}{l}\text { Genus species } \\
\text { Amara sp. }\end{array}$} & \multirow[t]{3}{*}{ Authority, year } & \multirow{3}{*}{$\begin{array}{l}\text { code } \\
\text { AMAR }\end{array}$} & \multicolumn{2}{|c|}{ Effect of city } & \multicolumn{6}{|c|}{ Effect of neighborhood design } & \multirow{2}{*}{$\begin{array}{r}5 \\
\text { result }\end{array}$} \\
\hline & & & \multirow{2}{*}{$\begin{array}{l}\text { F-ratio } \\
2.23\end{array}$} & \multirow{2}{*}{$\begin{array}{l}\text { p-value } \\
0.066\end{array}$} & \multicolumn{2}{|c|}{ Means in ND } & \multicolumn{2}{|c|}{ Means in CD } & \multirow{2}{*}{$\begin{array}{l}\text { F-ratio } \\
0.12\end{array}$} & \multirow{2}{*}{$\begin{array}{l}\text { p-value } \\
0.733\end{array}$} & \\
\hline & & & & & 0.013 & \pm 0.003 & 0.015 & \pm 0.003 & & & $\begin{array}{l}\text { result } \\
6\end{array}$ \\
\hline Asaphidion flavipes & (Linnaeus, 1761); & ASFL & 3.44 & 0.009 & 0.047 & \pm 0.014 & 0.038 & \pm 0.017 & 0.23 & 0.633 & \\
\hline Asaphidion stierlini & (Heyden, 1880) & ASST & 3.24 & 0.013 & 0.003 & \pm 0.001 & 0.016 & \pm 0.013 & 5.17 & 0.024 & $\mathrm{ND}<\mathrm{CD} 7$ \\
\hline Bembidion lampros & (Herbst, 1784) & BELA & 4.21 & 0.003 & 0.005 & \pm 0.002 & 0.014 & \pm 0.006 & 3.75 & 0.054 & \\
\hline Harpalus affinis & (Fabricius, 1792) & HAAE & 1.07 & 0.37 & 0.005 & \pm 0.002 & 0.006 & \pm 0.002 & 0.05 & 0.820 & 8 \\
\hline Harpalus rufipes & (De Geer 1774) & HARF & 8.39 & $<0.001$ & 0.023 & \pm 0.012 & 0.003 & \pm 0.002 & 12.22 & $<0.001$ & $\mathrm{ND}>\mathrm{CD}$ \\
\hline Nebria brevicollis & (Fabricius, 1792) & NEBR & 8.89 & $<0.001$ & 0.364 & \pm 0.086 & 0.174 & \pm 0.030 & 8.38 & 0.004 & $\mathrm{ND}>\mathrm{CD}$ \\
\hline Notiophilus biguttatus & (Fabricius, 1779) & NOBI & 7.88 & $<0.001$ & 0.047 & \pm 0.010 & 0.029 & \pm 0.007 & 2.98 & 0.086 & \\
\hline Notiophilus quadripunctatus & (Dejean, 1826) & NOQU & 7.42 & $<0.001$ & 0.055 & \pm 0.011 & 0.044 & \pm 0.009 & 0.80 & 0.378 & \\
\hline Pterostichus cupeus & (Linnaeus, 1758) & PTCU & 3.93 & 0.004 & 0.004 & \pm 0.002 & 0.007 & \pm 0.002 & 1.24 & 0.266 & \\
\hline Pterostichus madidus & (Fabricius, 1775) & PTMA & 9.40 & $<0.001$ & 0.009 & \pm 0.005 & 0.016 & \pm 0.006 & 2.27 & 0.133 & \\
\hline Pterostichus melanarius & (Illiger, 1798) & PTME & 3.22 & 0.013 & 0.000 & \pm 0.000 & 0.013 & \pm 0.013 & 9.45 & 0.002 & $\mathrm{ND}<\mathrm{CD}$ \\
\hline \multirow[t]{3}{*}{ Size class } & Size 1 & & 6.12 & $<0.001$ & 0.162 & \pm 0.027 & 0.147 & \pm 0.038 & 0.14 & 0.710 & \\
\hline & Size 2 & & 1.03 & 0.391 & 0.037 & \pm 0.006 & 0.047 & \pm 0.008 & 0.92 & 0.338 & \\
\hline & Size 3 & & 9.95 & $<0.001$ & 0.401 & \pm 0.087 & 0.219 & \pm 0.036 & 6.70 & 0.010 & $\mathrm{ND}>\mathrm{CD}$ \\
\hline Species richness & & & 12.65 & $<0.001$ & 2.333 & \pm 0.145 & 2.403 & \pm 0.204 & 0.09 & 0.761 & \\
\hline Total activity-density & & & 12.43 & $<0.001$ & 0.603 & \pm 0.093 & 0.421 & \pm 0.060 & 4.14 & 0.043 & ND $>C D$ \\
\hline
\end{tabular}


1 Table 3. Result of the GLM analysis of the effect of neighborhood design (CD=Conventional design; ND=new design) on species richness and 2 activity-density (total, mean per species and per size class) for the most abundant spider species (i.e. represented by at least $1 \%$ of total catches).

\begin{tabular}{|c|c|c|c|c|c|c|c|c|c|c|c|}
\hline \multirow{3}{*}{$\begin{array}{l}\text { Genus species } \\
\text { Agroeca inopina }\end{array}$} & \multirow{3}{*}{$\begin{array}{l}\text { Authority, year } \\
\text { Cambridge, } 1886\end{array}$} & \multirow{3}{*}{$\begin{array}{l}\text { code } \\
\text { Agrin }\end{array}$} & \multicolumn{2}{|c|}{ Effect of city } & \multicolumn{7}{|c|}{ Effect of neighborhood design } \\
\hline & & & \multirow{2}{*}{$\begin{array}{l}\text { F-ratio } \\
2.44\end{array}$} & \multirow{2}{*}{$\begin{array}{l}\text { p-value } \\
0.047\end{array}$} & \multicolumn{2}{|c|}{ Means in ND } & \multicolumn{2}{|c|}{ Means in CD } & \multirow{2}{*}{$\begin{array}{l}\text { F-ratio } \\
4.47\end{array}$} & \multirow{2}{*}{$\begin{array}{l}\text { p-value } \\
0.036\end{array}$} & \multirow{2}{*}{$\begin{array}{l}\text { result } \\
\mathrm{ND}<\mathrm{CD}\end{array}$} \\
\hline & & & & & 0.009 & \pm 0.003 & 0.018 & \pm 0.004 & & & \\
\hline Alopecosa pulverulenta & (Clerck, 1757) & Alopu & 6.07 & $<0.001$ & 0.017 & \pm 0.003 & 0.041 & \pm 0.013 & 6.98 & 0.009 & $\mathrm{ND}<\mathrm{CD}$ \\
\hline Clubiona comta & Koch, 1839 & Cluco & 5.34 & $<0.001$ & 0.018 & \pm 0.004 & 0.018 & \pm 0.004 & 0.01 & 0.906 & \\
\hline Clubiona terrestris & Westring, 1851 & Clute & 2.22 & 0.07 & 0.016 & \pm 0.003 & 0.012 & \pm 0.003 & 0.72 & 0.397 & \\
\hline Diplostyla concolor & (Wider, 1834) & Dipco & 0.89 & 0.47 & 0.009 & \pm 0.002 & 0.014 & \pm 0.003 & 2.25 & 0.14 & \\
\hline Drassodes lapidosus & (Walckenaer, 1802) & Drala & 7.96 & $<0.001$ & 0.015 & \pm 0.003 & 0.013 & \pm 0.004 & 0.35 & 0.555 & \\
\hline Dysdera erythrina & (Walckenaer, 1802) & Dyser & 3.10 & 0.016 & 0.046 & \pm 0.008 & 0.026 & \pm 0.005 & 4.87 & 0.028 & $\mathrm{ND}>\mathrm{CD}$ \\
\hline Enoplognatha thoracica & (Hahn, 1833) & Enoth & 5.03 & $<0.001$ & 0.012 & \pm 0.003 & 0.022 & \pm 0.007 & 2.98 & 0.085 & \\
\hline Erigone dentipalpis & (Wider, 1834) & Eride & 1.88 & 0.120 & 0.017 & \pm 0.005 & 0.011 & \pm 0.005 & 0.1 .00 & 0.319 & \\
\hline Hahnia nava & (Blackwall, 1841) & Hahna & 1.71 & 0.148 & 0.008 & \pm 0.002 & 0.027 & \pm 0.006 & 10.37 & 0.001 & $\mathrm{ND}<\mathrm{CD}$ \\
\hline Microneta viaria & (Blackwall, 1841) & Micvi & 4.07 & 0.003 & 0.028 & \pm 0.004 & 0.022 & \pm 0.005 & 1.27 & 0.261 & \\
\hline Neriene clathrata & (Sundevall, 1830) & Nercl & 1.83 & 0.124 & 0.020 & \pm 0.004 & 0.017 & \pm 0.004 & 0.36 & 0.549 & \\
\hline Ozyptila praticola & (Koch, 1837) & Ozypr & 3.82 & 0.005 & 0.079 & \pm 0.010 & 0.068 & \pm 0.009 & 0.69 & 0.406 & \\
\hline Pachygnatha degeeri & Sundevall, 1829 & Pacde & 6.62 & $<0.001$ & 0.009 & \pm 0.003 & 0.023 & \pm 0.008 & 5.42 & 0.021 & $\mathrm{ND}<\mathrm{CD}$ \\
\hline Pardosa amentata & (Clerck, 1757) & Param & 4.93 & $<0.001$ & 0.002 & \pm 0.002 & 0.027 & \pm 0.015 & 12.76 & $<0.001$ & $\mathrm{ND}<\mathrm{CD}$ \\
\hline
\end{tabular}




\begin{tabular}{|c|c|c|c|c|c|c|c|c|c|c|c|}
\hline Pardosa hortensis & (Thorell, 1872) & Parho & 3.04 & 0.018 & 0.226 & \pm 0.038 & 0.244 & \pm 0.036 & 0.13 & 0.722 & \\
\hline Pardosa prativaga & (Koch, 1870) & Parpr & 12.16 & $<0.001$ & 0.100 & \pm 0.032 & 0.052 & \pm 0.011 & 4.87 & 0.028 & \\
\hline Pardosa pullata & (Clerck, 1757) & Parpu & 9.00 & $<0.001$ & 0.028 & \pm 0.011 & 0.017 & \pm 0.007 & 1.75 & 0.187 & \\
\hline Pardosa saltans & Töpfer-Hofmann, 2000 & Parsa & 3.95 & 0.004 & 0.009 & \pm 0.005 & 0.025 & \pm 0.012 & 3.67 & 0.057 & $\mathrm{ND}<\mathrm{CD}$ \\
\hline Phrurolithus festivus & (Koch, 1835). & Phrfe & 2.92 & 0.022 & 0.009 & \pm 0.002 & 0.021 & \pm 0.004 & 7.38 & 0.007 & $\mathrm{ND}<\mathrm{CD}$ \\
\hline Pisaura mirabilis & Clerck, 1757 & Pismi & 5.43 & $<0.001$ & 0.027 & \pm 0.004 & 0.023 & \pm 0.006 & 0.39 & 0.532 & \\
\hline Scotina celans & (Blackwall, 1841) & Scoce & 0.67 & 0.620 & 0.014 & \pm 0.003 & 0.015 & \pm 0.004 & 0.09 & 0.767 & \\
\hline Tenuiphantes tenuis & (Blackwall, 1852) & Lepte & 3.17 & 0.015 & 0.016 & \pm 0.003 & 0.020 & \pm 0.004 & 0.75 & 0.386 & \\
\hline Trochosa ruricola & (de Geer, 1778); & Troru & 8.06 & $<0.001$ & 0.016 & \pm 0.004 & 0.057 & \pm 0.011 & 20.92 & $<0.001$ & $\mathrm{ND}<\mathrm{CD}$ \\
\hline Zelotes pedestris & (Koch, 1837) & Zelpe & 4.06 & 0.003 & 0.016 & \pm 0.011 & 0.012 & \pm 0.004 & 0.28 & 0.597 & \\
\hline Zodarion italicum & (Canestrini, 1868) & Zodit & 11.17 & $<0.001$ & 0.029 & \pm 0.007 & 0.049 & \pm 0.009 & 4.53 & 0.034 & $\mathrm{ND}<\mathrm{CD}$ \\
\hline \multirow[t]{3}{*}{ Size class } & Size 1 & & 4.59 & 0.001 & 0.258 & \pm 0.018 & 0.336 & \pm 0.027 & 6.98 & 0.008 & $\mathrm{ND}<\mathrm{CD}$ \\
\hline & Size 2 & & 1.98 & 0.098 & 0.381 & \pm 0.043 & 0.385 & \pm 0.040 & 0.00 & 0.947 & \\
\hline & Size 3 & & 0.46 & 0.766 & 0.321 & \pm 0.033 & 0.352 & \pm 0.034 & 0.44 & 0.509 & \\
\hline Species richness & & & 3.34 & 0.011 & 7.515 & \pm 0.353 & 7.958 & \pm 0.363 & 0.80 & 0.372 & \\
\hline Total activity-density & & & 1.86 & 0.118 & 1.031 & \pm 0.080 & 1.142 & \pm 0.081 & 0.96 & 0.327 & \\
\hline
\end{tabular}

1 
1 Fig. 1. Location of the 6 neighborhoods (conurbation of Rennes, Brittany, France); sites A to

$2 \mathrm{C}$ have conventional designs and sites $\mathrm{D}$ to $\mathrm{F}$ have new designs.

4 Fig. 2. Ordination diagram of the first two axes of Corresponding Analysis for 26 carabid 5 beetle species and 251 samples. For projection, the species fit range is from $3 \%$ to $100 \% ; 14$ 6 species are represented. The inverted triangle represents the new neighborhood design and the 7 star represents the conventional neighborhood design. Species codes are given in Table 2 and: 8 Haru=Harpalus rubripes (De Geer, 1774); Lefu=Leistus fulvibarbis (Dejean, 1826); Lopi=Loricera pilicornis 9 (Fabricius, 1775); Trec=Trechus sp.

11 Fig. 3. Ordination diagram of the first two axes of Corresponding Analysis for 69 spider species and 251 samples. For projection, the species fit range is from 3\% to 100\%; 39 species are represented. The inverted triangle represents the new neighborhood design and the star represents the conventional neighborhood design. Species codes are given in Table 3 and: Alocu=Alopecosa cuneata (Clerck, 1757); Atyaf=Atypus affinis Eichwald, 1830; Censy=Centromerus sylvaticus (Blackwall, 1841); Clure=Clubiona recluse Pickard-Cambridge, 1863; Draso=Drapetisca socialis (Sundevall, 1833); Hapsl=Haplodrassus silvestris (Blackwall, 1833); Harho=Harpactea hombergi (Scopoli, 1763); Micpu=Micaria pulicaria (Sundevall, 1831); Micsu=Micrargus subaequalis (Westring, 1851); Ozysi=Ozyptila 19 simplex (Cambridge, 1862); Pansu=Panamomops sulcifrons (Wider, 1834); Phrmi=Phrurolithus minimus Koch, 1839; Pirpi= Pirata piraticus (Clerck, 1757); Robar=Robertus arundineti (O. Pickard-Cambridge, 1871);

21 Steli=Stemonyphantes lineatus (Linnaeus, 1758); Trosc=Troxochrus scabriculus (Westring, 1851);

22 Trote=Trochosa terricola Thorell, 1856; Walac=Walckenaeria acuminata (Blackwall, 1833); Zelap=Zelotes 23 apricorum (Koch, 1876); Zelsu=Zelotes subterraneus (Koch, 1833); Zorsp=Zora spinimana (Sundevall, 1833). 
1 Fig. 1.

2

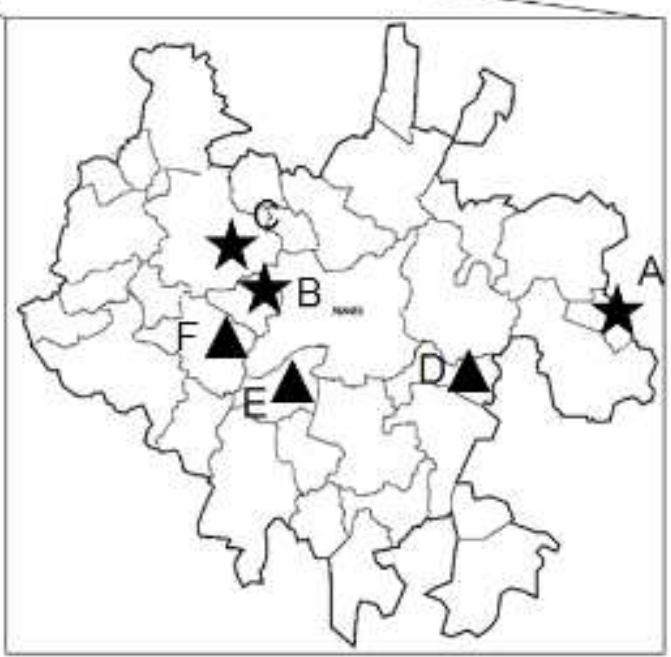


$1 \quad$ Fig. 2.

2

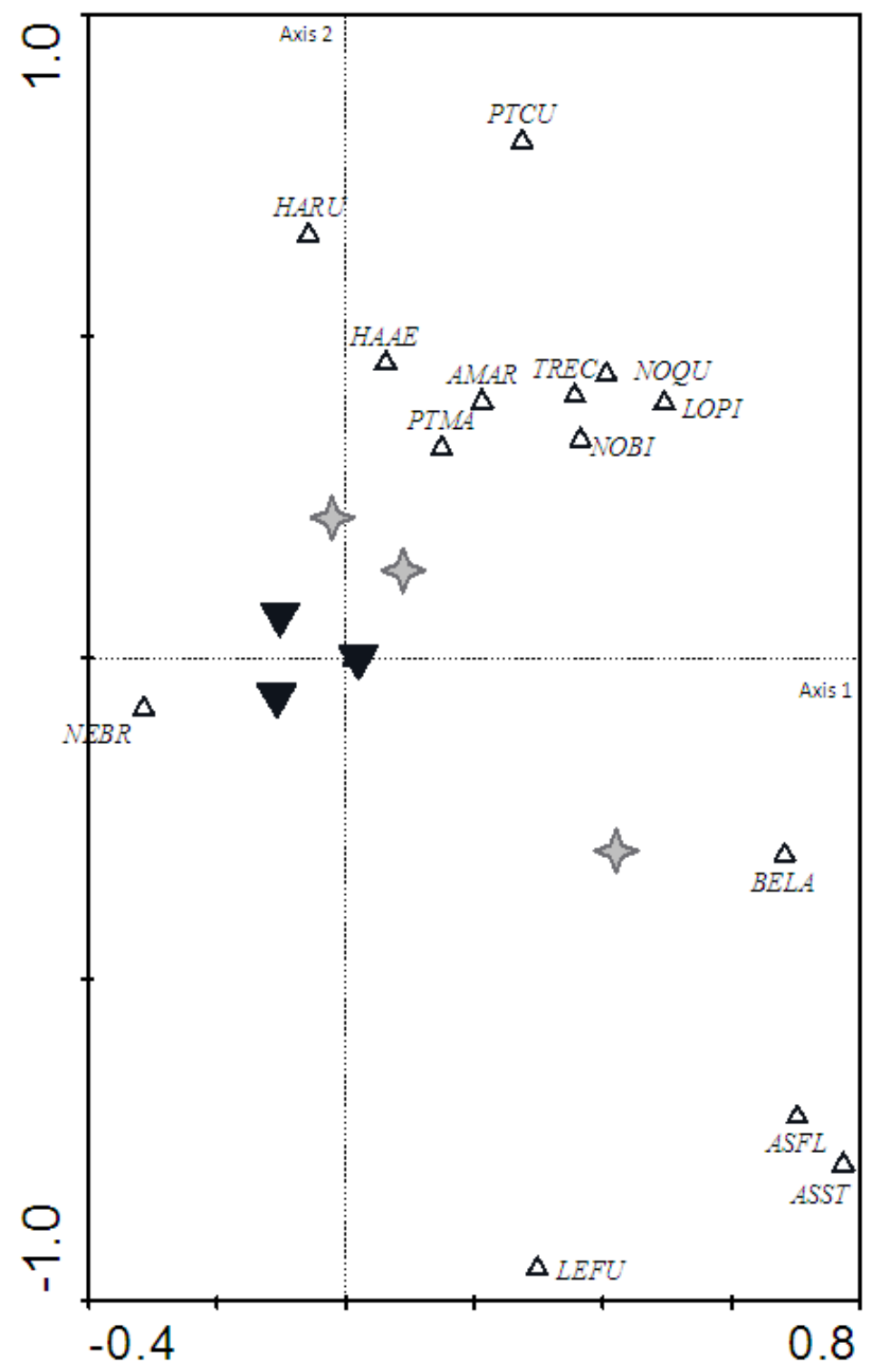


$1 \quad$ Fig. 3.

2

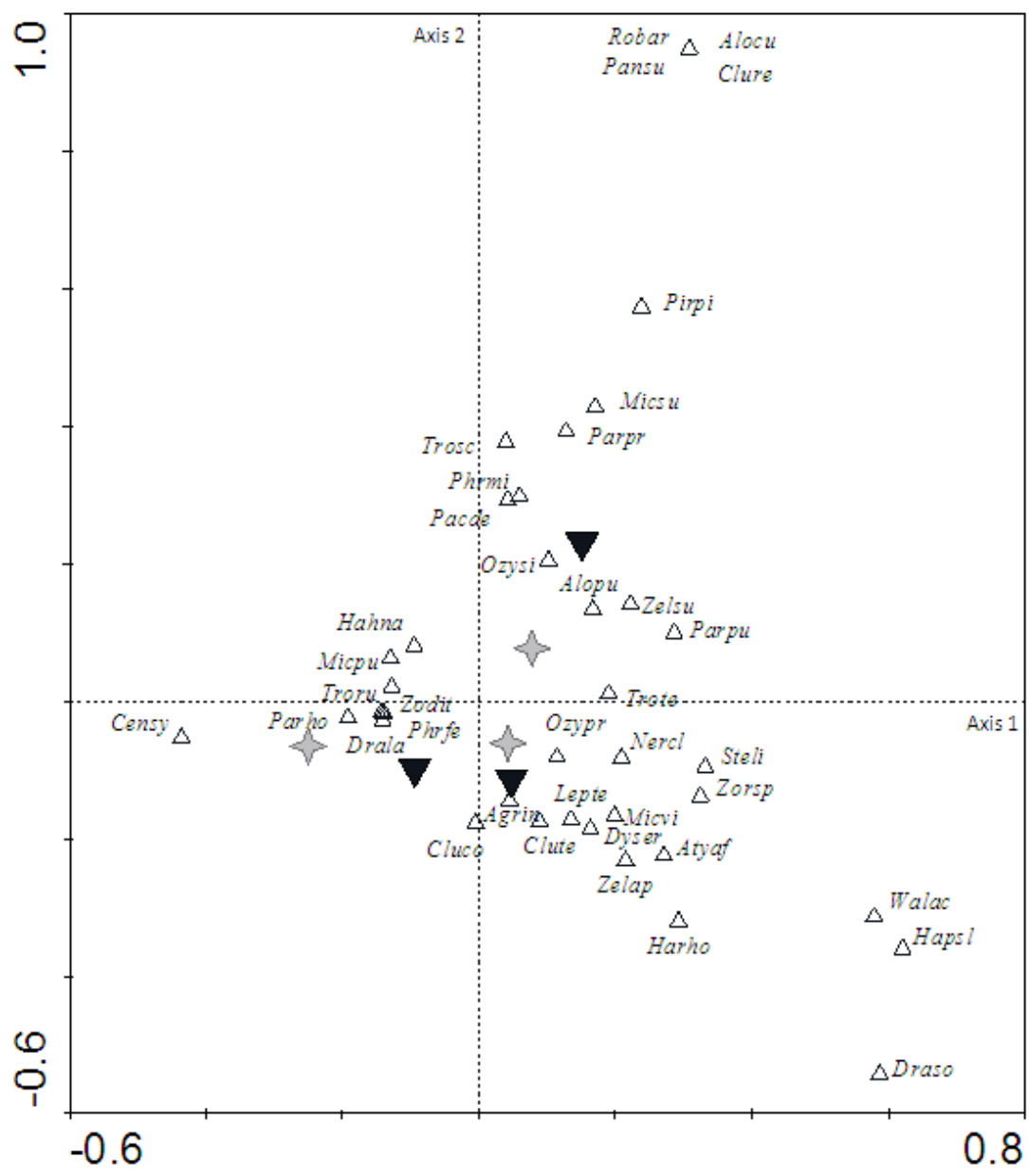

3

4 